$$
P E-082-04
$$

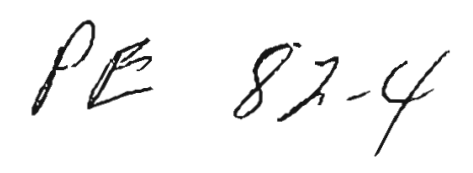

TERRITORY OF ALASKA

DEFAFTMISNT OF MINES

PROPERTY EXAMINATION REPORT

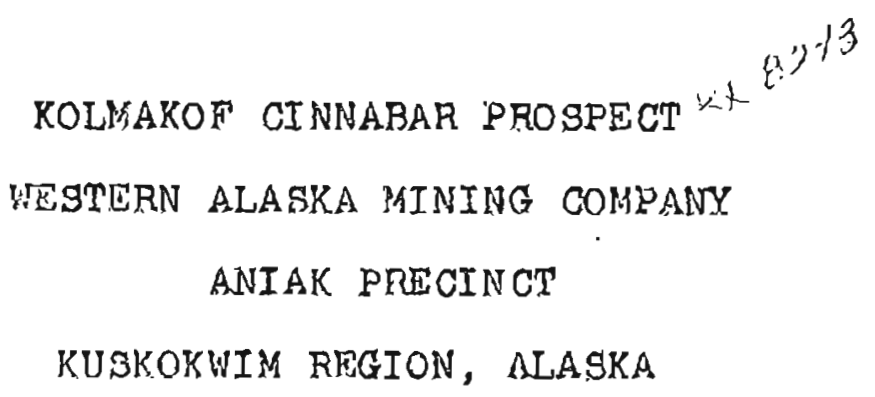

by

MARTIN W, JASPER

Assoolate M1ning Englneor

May - 1955 


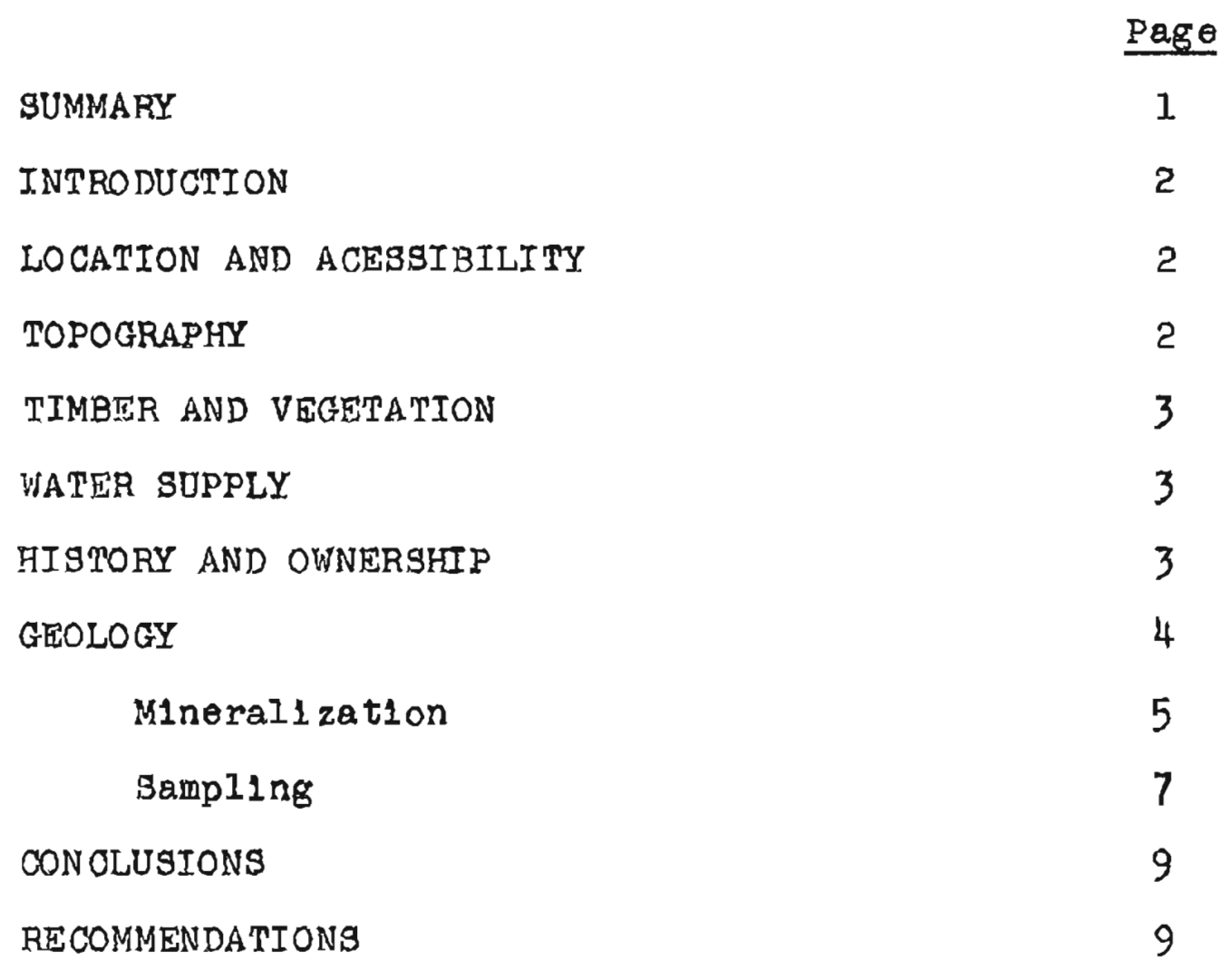

APPENDED

Maps No. 1 and No. 2

Plotures of Area - Plates 1 to 2 (Incl.)

RIEFIRENCR9

U.S. Bureau of Mines R.I. 4065. Pages 49-50

J.9.G.S. Bullet1n 622. Pages 273-4, 280 to 286

H1 story:- Ivan Petrov's Report on

Population, Industries and Resouroes

of Alaska 1884. Page 13, 77, and

90. First Mention.

J. E. Spurr, U.S.G.S. 20tb Annual. Report, Part 7, Page 261, 1900. 


\section{KOLMAKOF CINNABAR PROSPECT}

\section{SUNMARY}

The Kolmakof c1nnebar oocurrence is poss1bly the first one noted by the Russians, in the 1800's.

Although knom ior 75 to a 100 years, the 11 mited anount of exploration work done upon 1 t has been uneuccessful to date in determining the presence of ore bodies of economio interest.

Dozer stripping in August and September 1954 uncovered a lenge 24 feet in length, whloh oarrled palr values aorose 22 to 51 inch widths in sheared shales on hangingwall side of a narrow rhyolite sill. No other points of mineralization were noted in the 125 peet of stripping along the strike of the thin sill. An 年 to ll cinnabar stringer, etriking to northwest, wa uncovered and followed for 25 seet in the overlying sandstone.

It was reported Hay 9th, 1955 that a winze, sunk last month to depth of 10 feet, found no oinnabar mineralization below the 2 foot level.

* References: U.9.G.9. Bu1.622. Pages 280-286

$$
\text { U. B. B.M.R.I. 4065. Page日 } 48-4.9
$$


INTRODUCTION

At requegt of $R$. J. Anderson Associates (a partnersh1p known as the Western Alaska M1ning Company (WAMCO)) to examine the prospect and lay-out a dozer stripping program on the Kolmakof cinnabar poparty which they had recently located, the period from Auguet 28 to september 3. 1954 was spent on that project.

Al1 old workings and the dozer cuts were tied-in by Bruntontape traverse, and are shown on Maps 1 \& 2 attached.

Following the mapping of the area location for additlonal dozer atripoling in september was lala out.

LOCATION AND ACCESSIBILITY

Looated on a 250 foot bluff on north lde of the kuskokw1n RIver at extreme degtern limits of the river in the sleltmute quadrangle, Aniak precinct, it 1 ios about I mile east of geograph1 oal coordinate Long1 tude $159^{\circ} 00^{\prime}$, and Latitudo 6I0 361. It 1 approximately 20 m110s upatroam from Anlak, and 3 mile downstream from the old kolmakof Fort ruing.

It is accessible by dally scheduled Northern Consolidated Airlines planes from Anchorage to Antak and Bethel. From Anlak to the property an outboard motorbost was used. Float equipped planes can land on the Kuakowlm R1ver within 500 feet of the ahowing

The property 18 about $200 \mathrm{~m} 11$ es from mouth of the Kuskokwim River, and about 160 miles above Bethel.

Heavy Preight shipments into the region are handied by river boats from Bethel, where it is delivered by steamshipe from seattle.

TOPOGRAPHY

This 1mmediate area on north side of the river is one of low rellef, with a eneraliy rolling surfece gradualiy ring to 1000 to 2000 feet above gea level. Elevation of the river, below tize showings, is within linits of 150 to 200 feet, and the showing examined are 250 feet above 1.t.

- Refer to attached pletures. Also to U.3.G.S. Bul. 622. Page 280. 
"The north bank of the Kuskokwin fiver 19 made up ch1eply of roak bluefs from 100 to 400 seet high". "To the south of the river the area is one of a wide alluvial lowland valley.

The rivers with in this $V 1$ cinity $1 \mathrm{~s} \frac{1}{2}$ to $3 / 4$ mile. IIMBLER AND VEGETATION

only scattered scrub spruce is to be found on the property. However, thare $1 \mathrm{~s}$ an abundanoe of spmice sultable for mining timber and lumber along the river valley within a Pew miles of the property. Birch and poplar 1s abundant, with some birch noted of good size.

In the area on north side of the river the underbash growth is notheavy and offers easy travel across the country on foot and for tractor travel. The slopes have a falrly heavy moos covering, and perma frost was found in some of the outs for a few feet in thickness under the tundra.

WATER SUPPLY

A small streom, Intrenohed in a fault plane, is present on the property; 1t lies 500 to 1300 feet north of the biuff howings in vest half, and parallels the bluff edge at 100 to 200 feet in east half of mapped area. The stream flow would be sufflolent for oamp use.

HI BTORY AND OWNBRSHIP

The Kolmakof cinnabar occurrence wos known to the Russlans long before J. E. Spurr's referenoe to 1 t in 1898. *tt

During his reconnalesance of the Kuskowira region that year Spurr mentions that a trader, Mr. Iind, had found a cinnabar veln several yeara before on the Kolmakof property, and that Lind had spent 2000.00 minling some of the ore, whl ch was shipped to the states at a 1088. sinall excavations along the bluff slopes.

A. A. Maddren, in 1914, also found that the clnnabar 1nalcations were obsoure, al though woris was reported to have been done on the occurrenoes elnoe that of Mr. Lind.

A Mr. Rabideal is reported to have hold the ground for many years and that a sali amount of quicksilver was "U. S.G.S. Bul. 622. Pages 280-81 *Map 1, attached. \#. W. G. 5. Twentieth Annual Report, Part 7. Page 261,1900. *. G.S. Bul. 622. Page 273, 1914.

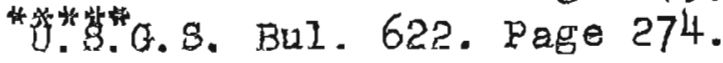




\section{$-4-$}

produced in a homemade retort at his home a mile or so downetreem on south bank of the Kugkokwim river. It is not clear when he or others put down the two old rinzea; one of these 1 s located 75 feet from bluff edge (vertical and of undeterminod depth), and the other 675 seet to northeast, sunk on a $50^{\circ}$ to $60^{\circ}$ slope and ala to be 80 feet in dopth, although the dump indientes it to be much shallower. The pirst noted winze was largely destroyed by dozer cut No. 3-CT, a short time before the 1954 examination, and tho other was filled with water."

lihe property was optiloned or relocated (?) in 1907 or 1908, by Gordon Pettles of Nome and the Bettlos adst was driven an undeternined distence.

The property was held by H1l1e Rabldeau, son of the oldtimer, for a number of years, prior to 1953.

The property ras relocated in 1954 by the raMco group.

\section{GFIOTOGY}

The formation in vicindty of the Kolmakof prospeot $1 \mathrm{~s}$ I1mited to sendetone (arkosio and quertzose) and shalo, which are well-exposed for the most part half way up the blurf. These interbedded sediments are of great thlokness, and are olassed as upper oretaoeous for lower tert1ary) slmilar to other sectiong of Kuskokw1m region. The sandatone beds have the greater widthe, varying from a lew feet up to 30 feet or more in thickness, while the shaleg appear to range erom thin layers to 2 to 5 foot thick.

A number of 8111 s have been reported in the district. 3trike of the sediments locally ranges from $N 45^{\circ}$ to $75^{\circ} \mathrm{E}$ and their dip varieg from $110^{\circ}$ to $60^{\circ} \mathrm{NW}$.

Two shyolite $8111 \mathrm{~B}$, (Identifled as andesite by U. 3.G.3.), are known to be present; the westerly one exposed and followed 125 peet in cut No. 4-CT, and one showing in bluff below but not exposed in cut No. 3-CT. 250 feet east. The p1rat noted sill varies in widt from 2 to 5 feet where atripped in the cut; it 1 s obsoured by the bank "ereep" to lerge extent on the steop bluff slope. The second 8111 is also largely obsoured, but is reported

"Reper to Map I.

* U. S.G.9. BuI. 622, Page 283-84. - Refer to kap 2, attached. *.s.G.S. Bur. of Mines. R.I. 4065, Page 50, F1g. 21. 
to be 1 to 2 feet thick.

During courge of surveying and mappling in 1954 plotting of the 8 trenches atill in evidence on bluff slope excavated by U.3. Bureau of Mines in 194l indioates their was along 5 to 30 poot 8111 and shown on the1r Figure 21, th and is the same narrow 111 uncovered in cut No. 4-Cr. However, 1 t true with on the slope was also largely obsoured by bank "creeps" and by the material puahed over the bluff edge by the dozer.

Whearling along the shale bedalng (on hanging-wall slde of s1li) was noted in No. 4-CT cut, and two faults aro shown a.t west end of this same cut.

Several feet of glacial clay was present in number of the 1954 dozer outs; the residual reathering of the sediments extends from 5 to 15 feet below the clay, espeolally near the bluff adge.

\section{Mneralization}

The olnnabar mineralizetion, a el gewhere in the Kuakokw1m region, is asoociated with and followed the intrugion of a1119. With the U.S. Bureau of Mines 1944 trenches sloughed-1n and In number of cases obscured by "creep" of the steep bluff slope, and the Bettles adit and old winze inaccessible, obgervetions of the mineral oocurrences were $11 \mathrm{mlted}$ to the showing exposed by dozer trench1ne in 1954.

Due to inexperience of the owners and the contractor doing the siripping, trenching done prior to the examining eng1neer arrival on the property had not loceted the alil on top of the blupe which the t.S. Bureau of Mines had traced on the slope below. Cut No. 4-CT was then laid out and the s1ll with some good clnnabar values in 1 ts hanglngwall shale was uncovered within an hour and a half.

With overburden depth along strike of sill renging from 10 feet on east end to 18 feet on west side of this cut, and perne frost present at north alde, four days were reaulrea to strip 125 feet and remove 3500 cuble yards to the bluff etge.

*U.S.G.3. Bul. 622, page 283-84. Refer to Map 2, attached.

*... Bur. of Minea. R.I. 4065, Page 50, F1g. 21. qu Refer to Map 2, attached. 
In stripping the 125 feet along the sill from oat to west a ahort lense, 24 feet in length and carrylng good valueg was exposed in the shale on hanging-wall of the narrow ( 2 to 5 feet) a111. It was noted that in cutting down the zone lit to 2 feet to expose more sol1d bedrook, the dozer got down below I Im1ts of mineral1zation at the east end for length of about 5 feet and exposed an approximately equal length of mineralization on the west end." This suggested the short ore-shoot to have very Iimlted vertioal range and "plunged" a.t amall angle to the west.

The cinnabar occurs as small "poda" or bunches, 8.s short alscontinuous veinlets, and as "blebs" and aleseminated grains in a strongly ahoared shale. No other aulfides were noted to be presont. A littlo oalol te was observed. at a Pow points.

The naryow 3111 is well fractured but no olnabar was noted in it throughout 1 ts expoged length.

A croas-frecture, having a N62w atrike and $50^{\circ}$ to $55^{\circ}$ south dip, was unoovered in the hanging-wall sandetone. This wea traced 30 peet and 1a filled with to 1 inoh of "soft" (weathered) olmabar, wh tho other gulfines noted. The inch or two of gouge-like material along the walls is probably aue to hydrothermal alteration of the arisosic gandstone as no fault movement is evident along this eracture plane. stripping to the northwest encountered frozen ground go that 1 t was not determined whether the stringer contlnued beyond point ahown on kap 2, a.]. though Indicationg at that time sugrested it a1d not.

The only other indicetions of clnngbar mineralization was found in cut No. 3-CT; this trench was completed before date of visit.

A helf dozen or more pieces - 1. to 3 inche in alameter were found in west bank of cut a fow feet above bedrock. Depth of olay and residually weathered shales and arkosio gandstone at this point is 18 feet. A few pleces of simlilar size were reported found on (or in?) bedrock, a.t though on exanination of the cuts floor no cinnabar was observed. No cinnabar was noted in dumo of sinze on east slae of out No. 3-cT; it is posstble that any ore encountered was carefulty sorted out and retorted by the miner who sunk the winze.

* Refer to Map 2, attachod. 
No cinnebar was noted in durop of the inolined winze 650 Peet to northeat, al though $0.16 \%$ Hgs. Was obtained in a "grab" sample. If eny ore was found during course of that work $1 \mathrm{t}$ may al 80 have been sorted and retorted.

All old trenches known by prosent owners were checked and no clnnabar observed in thelr dumps. None of the material remover from the Bettles adit remalns on the blufe slope; it has been removed during perlods of high water or "I ce-jams" and washod into the river.

\section{Sampling}

Fourteen channel samples were taken of the short lense In cut No. 4-CT and one grab sample of the inolined shaft dump. Description of the se are as followg and locationg ahown on Map 1, attrohed:-

1954 Sampling Reeults

\begin{tabular}{cccc}
\hline No. Nidth & Meroury & Looation & Description \\
\cline { 2 - 4 } & Ins. & Lb8/T & \\
\hline
\end{tabular}

\begin{tabular}{|c|c|c|c|c|c|}
\hline $1-T A$ & 24 & 0.38 & 7.6 & $4-C T$ & $\begin{array}{l}\text { Floor of cut. Sheared shale. } \\
\text { Irreg. "blobs" \& few flne } \\
\text { velniets Hgg. }\end{array}$ \\
\hline $2-W A$ & 22 & .2 .78 & 15.6 & $4-C T$ & $\begin{array}{l}\text { FJoor, sheared shale. HGS } \\
\text { os di aemmination \& fine } \\
\text { ohort velniets. }\end{array}$ \\
\hline$-W A$ & 24 & 8.488 & 169.6 & 4-CT & $\begin{array}{l}\text { Floor, sheared shale. No } \\
\text { Hgg noted l.n } 15^{H} \text { on Fy side. } \\
9^{11} \text { on HW blde composed of } \\
\text { small lense and. few stringers. }\end{array}$ \\
\hline $4-y_{A}$ & 24 & 0.38 & 7.6 & $4-C T$ & $\begin{array}{l}\text { Floor, sheared shale. Con- } \\
\text { tinuation of sample } 3 \text {-WA on } \\
\text { Hof slde. Two flne veinlets and } \\
\text { little dissem. Hog. }\end{array}$ \\
\hline$-W_{A}$ & 21 & 3.47 & 69.4 & 4-CP & $\begin{array}{l}\text { Floor, sheared shale, full } \\
\text { width of maln minerailzed sec- } \\
\text { tlon next to sill. Hgs as } \\
\text { blebs \& volniets. }\end{array}$ \\
\hline $6-15 A$ & 30 & 0.81 & 16.2 & $4-C T$ & $\begin{array}{l}\text { Floor, sheared shale. Contin- } \\
\text { uation of } 5 \text {-WA on HW slde. } \\
\text { Pew blebs \& littie fine grain- } \\
\text { od digeminated Hgs. }\end{array}$ \\
\hline $7-4 A$ & 24 & 1.19 & 23.8 & $4-C T$ & $\begin{array}{l}\text { Tloor sheared shale. Blebs } \\
\text { and flne velnlets. }\end{array}$ \\
\hline
\end{tabular}




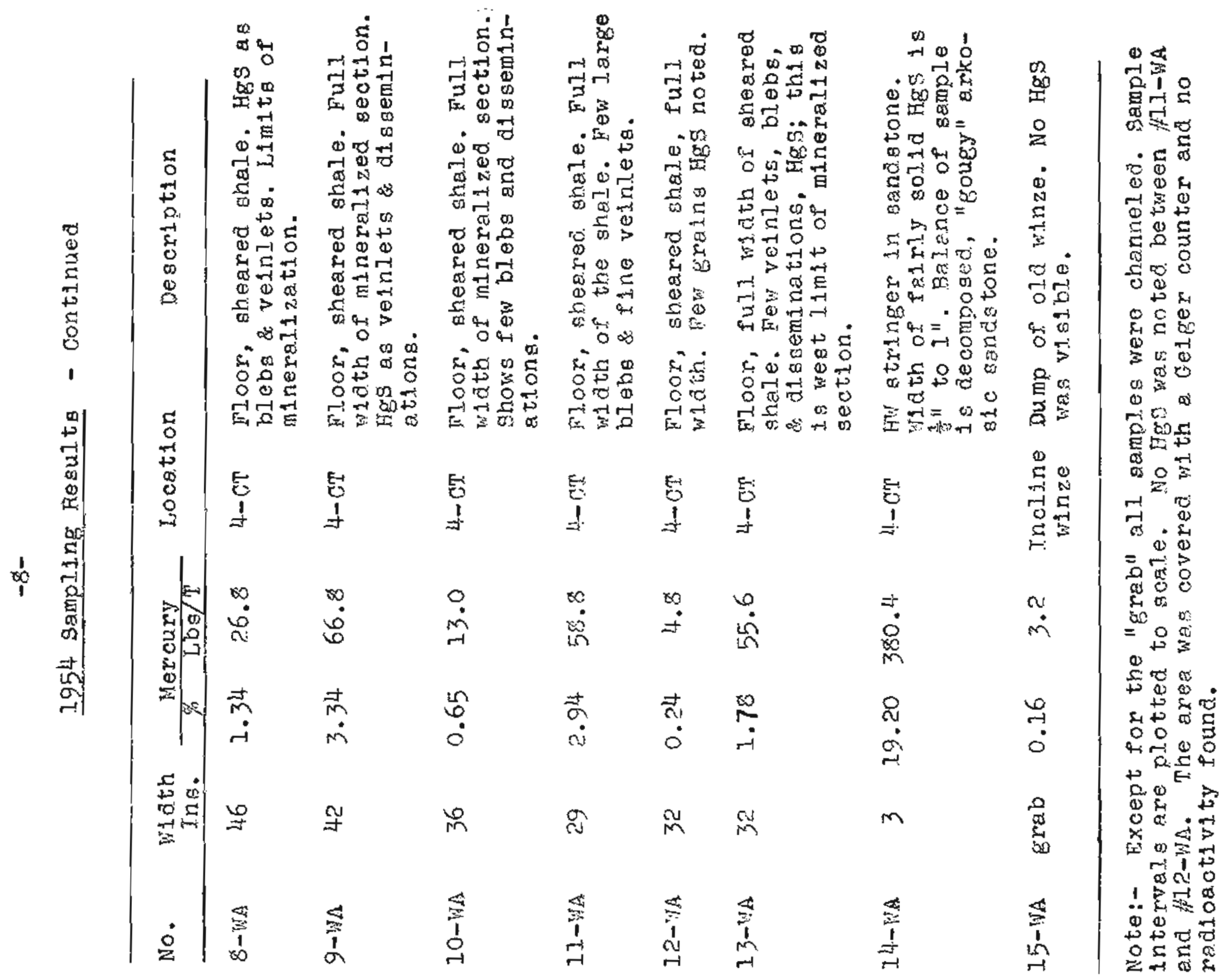


CONCLUSTONS

From work done and regults obtained along the sill by the U.S. Bureau of kines in 1944t and by the present owners stripping program in 1954, no encouraging evidence has been $f$ ound that woujd Indicate a "falr chance" of localing ore-shoots or lutneralized zones of economic importance in this vioinity.

The ore occurrences found by the U.S. B.M. In their trenching were 1 soloted enu.l.]. "pods", a thin velulet along a. few eractures eoross the sill, a silightily ininerolized 2 foot wide shear zone along the glils footwall, and $\theta$ narrow (average width $\frac{1}{2}$ 1nch) pers1stent highgrade olnnabar stringer traced. by trenobes at Intervals 250 feet up the slope for vertical diatance of 100 feet. This jattex offers possiblilty of a very small tonnage, wblle the other oocurrenoes $5.2 \mathrm{mining}$ widhs would be too low grade.

The ore-shoot exposed for Jength of 24 feet and width of 22 to 51 inches in out $\mathbb{1 0}$. 4 CT has good values but is an $180-$ lated occurrence believed to have a shal low depth. This was indicated in deepening this cut whisch in 2 feet reached the bottom and removed 5 feet of thi $s_{a}^{o r e}$ lense. Additional proof of $1 \mathrm{ts}$ probable shallowmess was obtained during April 1955, when a winze was sunk on the hlghest grade aectlon to denth of 30 feet; the mines reported last weels that no values were founi from point 2 feet below surface to bottom of the winze.

Notlzing of interest was found in the other trenches excavated by dozer last year prior to time of examination riate; unueugl$1 \mathrm{y}$ wet weather made the overlying clay and residually weythered bedrock 1mpractioal to remove to solla bedrock exoept at bluffe end of cut No. 3-CT. Cut No. 8-CM we. not completed later in september due to perma frost at upper end and softness of ground at south end.

Examinetion of the old winze dumpe shows nothing of sufilolent Interest to encourago adaltional work in that section.

From surface indication as well ag bedrock exposures in cut 1Yo. 3-C'C there appesirs to be no justiflcation por cleaning out and examining the old bettieg adit.

\section{RECOMEHITDATONS}

The Pollowing 1 lmited program was suggested:-

1. Sink winze to 20 to 30 seet depth at looation marked on Mav 2, In cut No. 4-CT. ghould good values continue to that 
depth, drift to west and east to determine limitis and values of lenee (ore-shoot).

Should v8lues and length of lense justify, sink an additional 20 to 30 peet, and arift to west and east. Abandon project if cinabar mineralization is bottomed Ln first seotion of winge.

2. Make dozer cut No. Th a ang line marked on the ground to bedrock. Th1 8 w1ll oross-out both dikes. If no value are rauna there will be no juetifioation for additional cuts paraliel to it to the northeost; should good valuea be found striplontrike of minorallzed zone ds encountered, and/or make adatilonal parallel cuts.

Favorable results from this work will determine future program to follow.

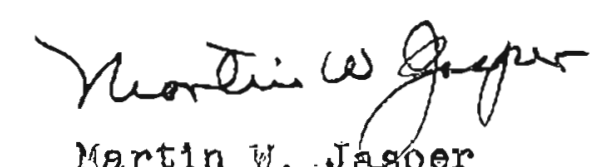

Martin W. Jagper

Associate kining fingineer Territorial vepartment of Mines

Anchorage, Ala.5ke.

May $] .2,1.955$ 
KOLMAKOF CINNABAR PROSPECT

$$
\text { Aug. 31, } 1954
$$

V1ew looking N40w from River bank. w1 th Cut No. 4 CT.

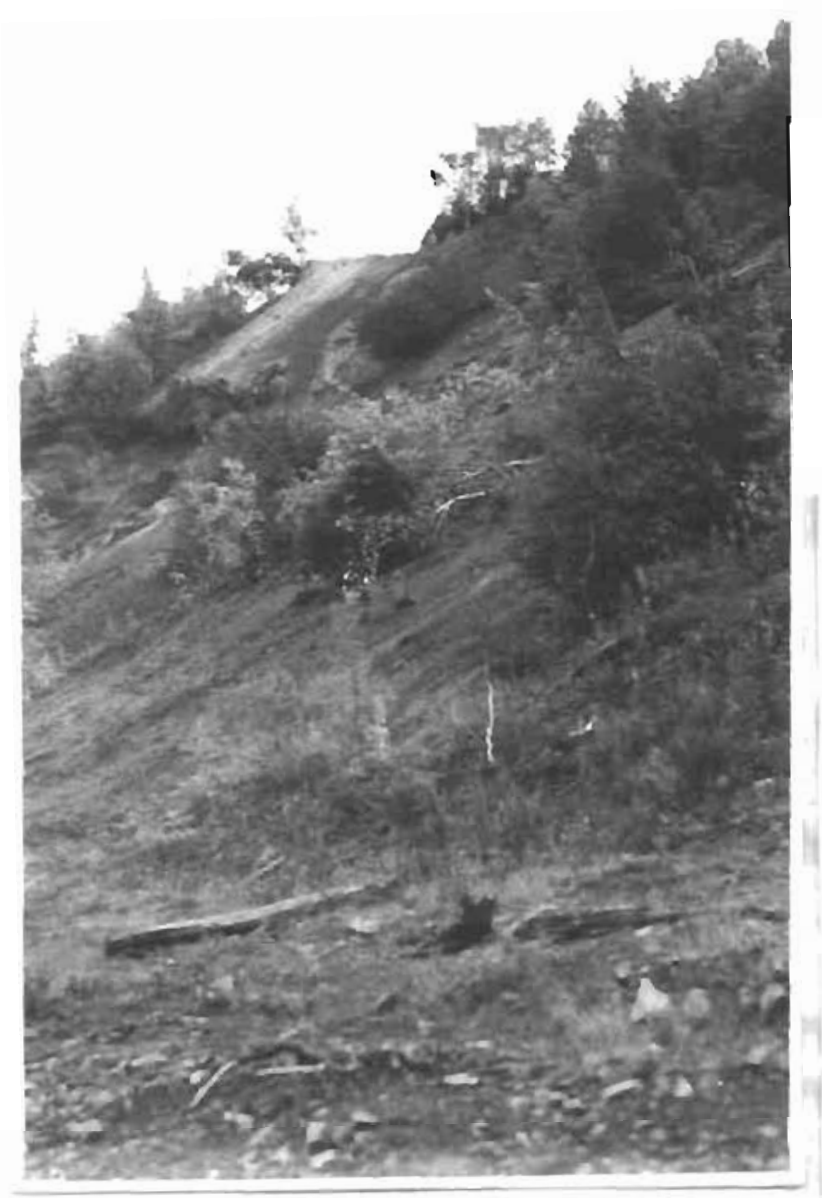

Dump Cat bluff edge in center background.

Sept. 1, 1954

V1ew looking $\$ 65 W$ showing depth of stripping in Cut No. 4-CT. Trench in Cut exposed ore-shoot in foreground for 25 feet.

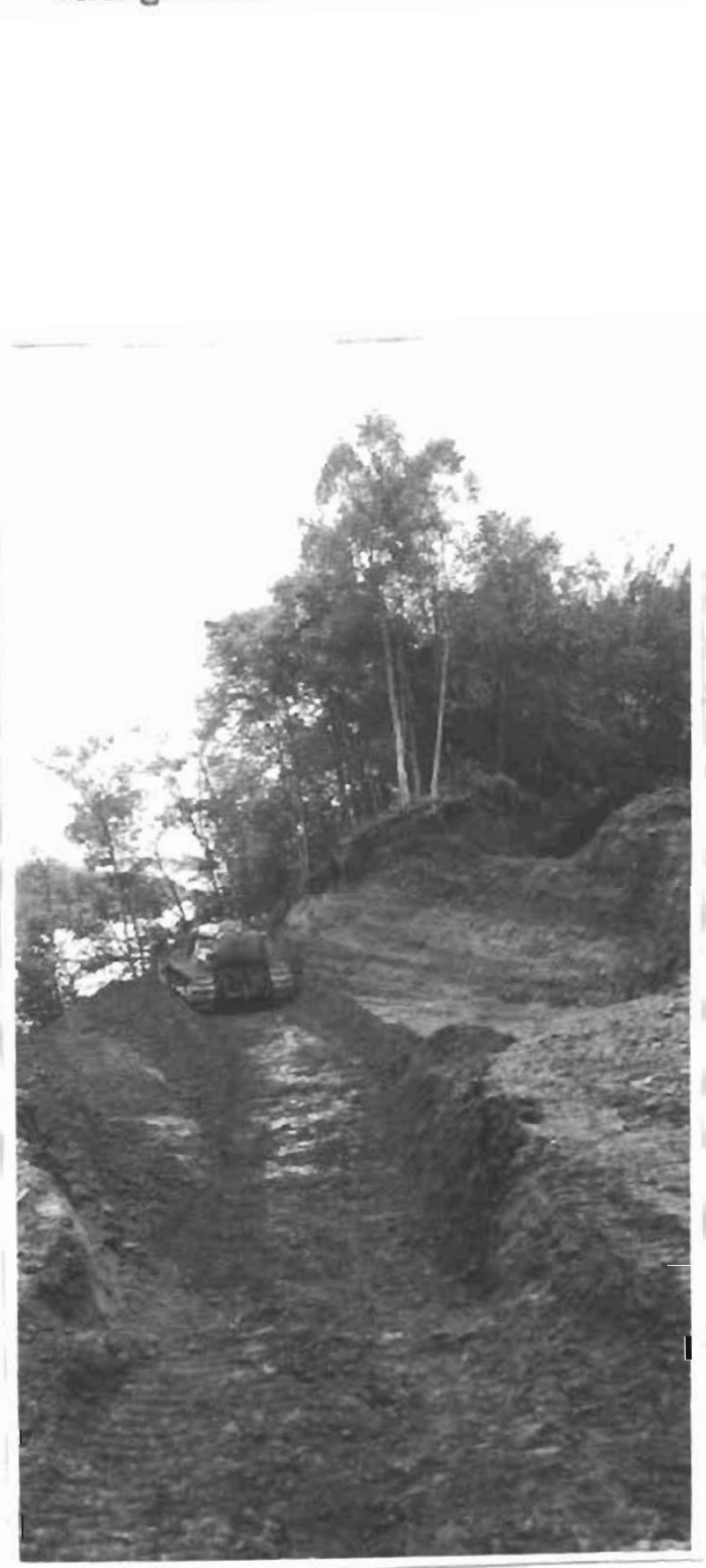




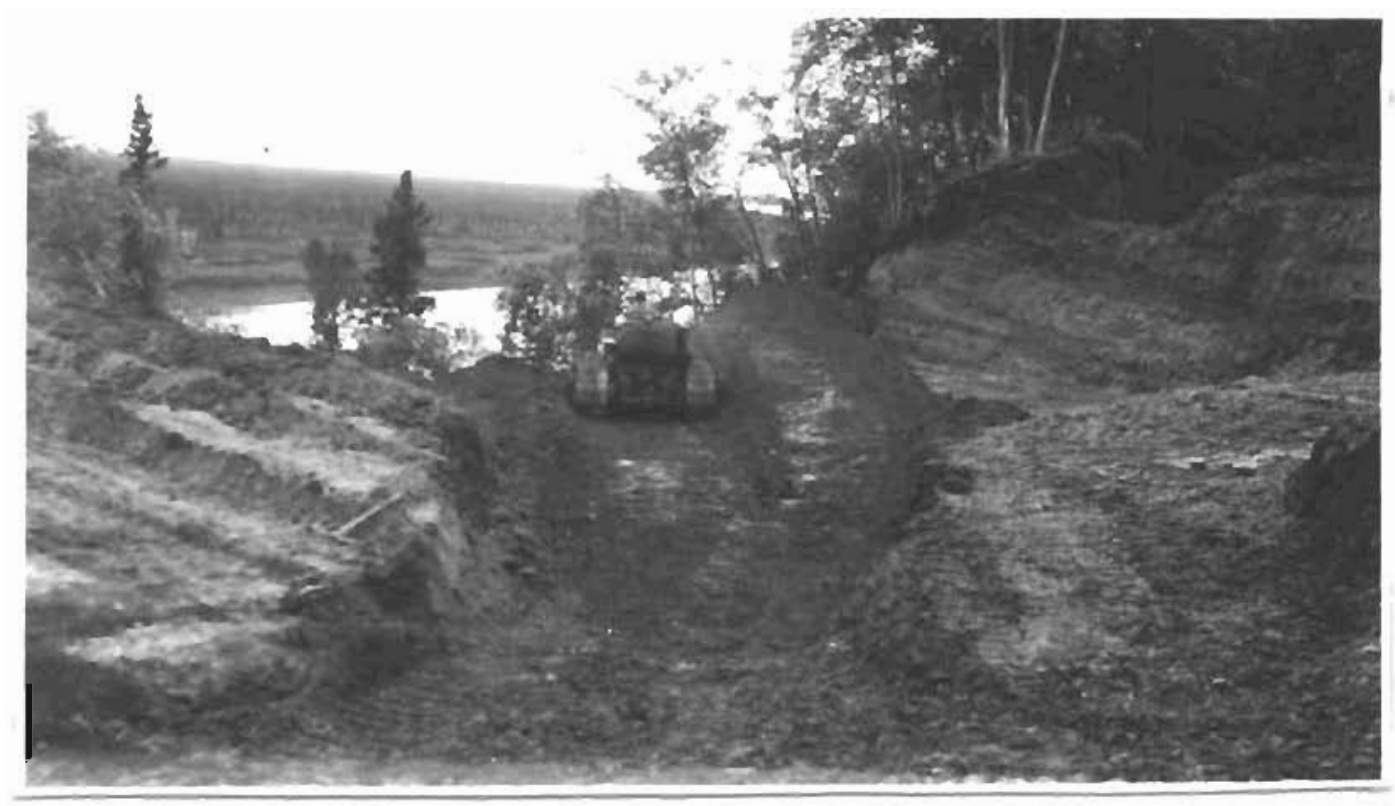

Sept. 1, 1954

Cut No. $4 \mathrm{CT}$. Cat cutting down trench following bedding of minerallzed shale and sill. "Warped" sediments due to fault cutting formation at $45^{\circ}$ angle at point under tractor. Short ( 25 ' long) ore-shoot (lense) in center foreground.

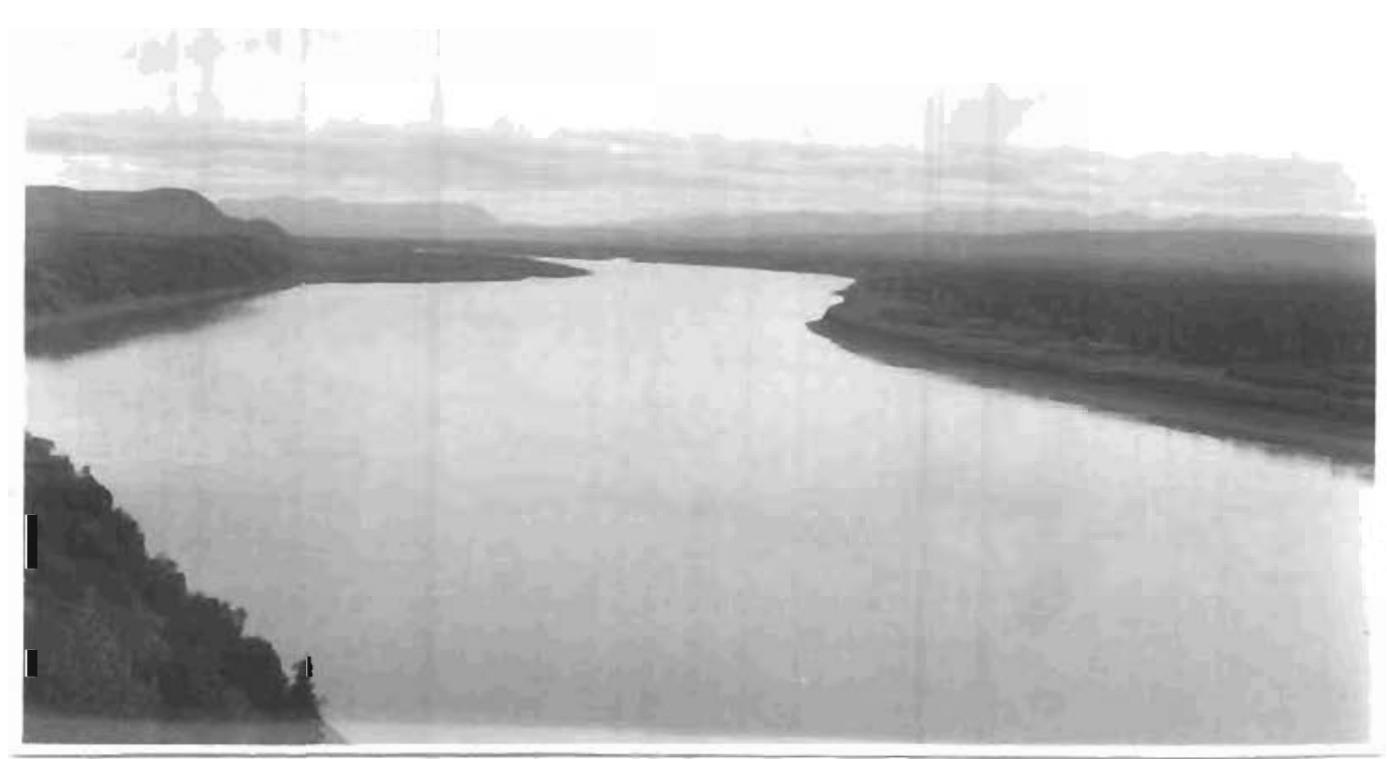

Sept. 1, 1954

Looking $555^{\circ}-60^{\circ} \mathrm{E}$ and upstream, showing low rellef of Kuskokw1m R1ver valley. Taken from bluff edge at Cut No. 4-CT. 